\title{
Ectoparasitic flies (Diptera, Streblidae) of bats (Chiroptera, Phyllostomidae) in an Atlantic Forest area, southeastern Brazil
}

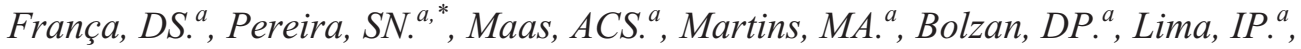 \\ Dias, $D{ }^{b}$ and Peracchi, $A L^{a}{ }^{a}$ \\ ${ }^{a}$ Laboratório de Mastozoologia, Instituto de Biologia, Universidade Federal Rural do Rio de Janeiro, \\ BR 465, km 7, CEP 23890-000 Seropédica, RJ, Brazil \\ ${ }^{b}$ Laboratório de Biologia e Parasitologia de Mamíferos Silvestres Reservatórios, Fundação Oswaldo Cruz, \\ Avenida Brasil 4365, CEP 21040-360 Manguinhos, Rio de Janeiro, RJ, Brazil \\ *e-mail: spereirabio@gmail.com
}

Received July 31, 2012 - Accepted November 27, 2012 - Distributed November 29, 2013

(With 1 figure)

\begin{abstract}
We studied infestation rates and parasite-host associations between streblid flies and phyllostomid bats in an Atlantic Forest area of Rio de Janeiro state, southeastern Brazil. We captured 301 individuals from seven Phyllostomidae bat species. Out of that total, 69 bats had been parasitised by nine Streblidae species; the most frequent species were Trichobius joblingi and Trichobius tiptoni. The species Paraeuctenodes longipes, associated with Anoura geoffroyi, was the most frequent species. The highest mean intensity was observed for Paraeuctenodes longipes, associated with A. geoffroyi, and Paratrichobius longicrus associated with Artibeus lituratus, both ectoparasite species with a mean intensity of five individuals per bat. Trichobius joblingi exhibited the highest mean abundance, which was over three on its host species. Streblid richness in the study area was similar to the richness found in other studies carried out in the Atlantic Forest. We observed that streblid richness in this biome depends more on inherent characteristics of each physiognomy and on the host-species than on the sampling effort.
\end{abstract}

Keywords: streblids, richness, chiropterans, infestation patterns.

\section{Moscas Ectoparasitas (Diptera, Streblidae) de morcegos (Chiroptera, Phyllostomidae) numa área de Mata Atlântica, sudeste do Brasil}

\section{Resumo}

Estudou-se as taxas de infestação e as associações parasita-hospedeiros de dípteros estreblídeos ectoparasitas de morcegos filostomídeos, em um fragmento de Mata Atlântica, no estado do Rio de Janeiro. Foram capturados 301 indivíduos de sete espécies de morcegos da família Phyllostomidae. Desse total, 69 morcegos encontravam-se parasitados com nove espécies de Streblidae, sendo Trichobius joblingi e Trichobius tiptoni as espécies mais freqüentes do total de estreblídeos coletados. Paraeuctenodes longipes, associada à Anoura geoffroyi foi a espécie mais prevalente. A maior intensidade média foi encontrada para Paraeuctenodes longipes, associada à A. geoffroyi e Paratrichobius longicrus associada à Artibeus lituratus, ambos com cinco ectoparasitas em média por morcego infestado. Trichobius joblingi apresentou a maior abundância média de infestação, que foi superior a três nas espécies de hospedeiros em que foi encontrada. A riqueza de estreblídeos da área de estudo é similar àquela obtida em outros estudos realizados na Mata Atlântica, e verificou-se que a riqueza de estreblídeos nesse bioma depende mais de outras características inerentes a cada fitofisionomia e à espécie hospedeira do que do esforço amostral de coleta.

Palavras-chave: estreblídeos, riqueza, quirópteros, padrões de infestação.

\section{Introduction}

Bats can be parasitised by over 600 species of arthropods belonging to the Siphonaptera, Diptera, Hemiptera, Dermaptera, and Acari (Marshall, 1982). The order Diptera includes hematophagous species that belong to two families, Streblidae and Nycteribiidae, which are exclusive bat ectoparasites (Wenzel et al., 1966; Marshall,
1982). Species of Streblidae have a cosmopolitan distribution and exhibit high species diversity in the New World; they are mainly associated with the bat family Phyllostomidae (Dittmar et al., 2006; Dick and Patterson, 2007). In Brazil, 72 species are listed in this dipteran family (Eriksson et al., 2011; Graciolli and Azevedo, 2011; Graciolli and Dick, 2012). These flies can be mobile, since $78 \%$ of the species have functional wings (Rui 
and Graciolli, 2005). However, they are extremely adapted to parasitism and spend most of their lives on the body of their host, feeding continuously; or they remain in their host roosts, feeding during the inactivity periods of their host (Marshall, 1981). Knowledge of bat flies biology and ecology can provide important information about the biology of their host, as well as a better understanding of the ecology and behaviour of bats in their roosts (Patterson et al., 2007).

Studies on bat flies in Brazil comprise mainly taxonomic inventories, records of species occurrence in restricted areas (Graciolli and Rui, 2001; Graciolli and Linardi, 2002) or quantitative data on richness and abundance of streblids and nicteribiids (Komeno and Linhares, 1999; Bertola et al., 2005; Graciolli and Bianconi, 2007), as well as infestation patterns (Rui and Graciolli, 2005; Santos et al., 2009; Esbérard et al., 2012). Those studies were carried out in different states in all Brazilian regions, covering several biomes, though they still have many gaps. In the Atlantic Forest, most studies were concentrated in the southern region (Graciolli and Rui, 2001; Rui and Graciolli, 2005).

In order to contribute to the knowledge of the distribution and host-parasite relationships of bat flies in southeastern Brazil, which are poorly known for the state of Rio de Janeiro, we studied a streblid fly assemblage associated with phyllostomid bats and its infestation rates in an Atlantic Forest fragment, using indexes of prevalence, mean intensity of infestation and mean abundance of infestation. Then we compared streblid richness found in the present study with richness from other localities assessed in studies carried out in different physiognomies of the Atlantic Forest.

\section{Material and Methods}

The Instituto Zoobotânico de Morro Azul (IZMA) is a private reserve, with 19 hectares of second-growth Atlantic Forest, located in the municipality of Engenheiro Paulo de Frontin, in Pau Ferro Mountain Range (22 $29^{\prime}$

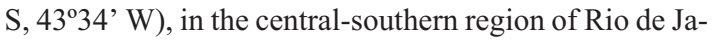
neiro State (Figure 1). Altitudes vary from 671 to $825 \mathrm{~m}$ a.s.l. The local vegetation is characterised as semideciduous forest and the climate is Cwa, according to Köppen's classification: mesothermal climate, with hot and rainy summers; January is the hottest month and July is the coldest. Annual average rainfall is $1,200 \mathrm{~mm}$; October is the driest month and January is the rainiest (Furusawa and Cassino, 2006).

Sampling was carried out from September 2007 to June 2009, totalling 16 nights of capture, carried out independently of moon phase. In each sampling night, ten mist nets were used: two 12-m nets, seven 9-m nets and one 5-m net, set up at ground level before sunset and kept open for $12 \mathrm{~h}$ (Esbérard and Bergallo, 2005), totalling a sampling effort of 441,600 $\mathrm{m}^{2} \mathrm{~h}$ (following Straube and Bianconi, 2002). Nets were checked every $20 \mathrm{~min}$.

The captured bats were identified in the field using identification keys from Emmons and Feer (1997) and

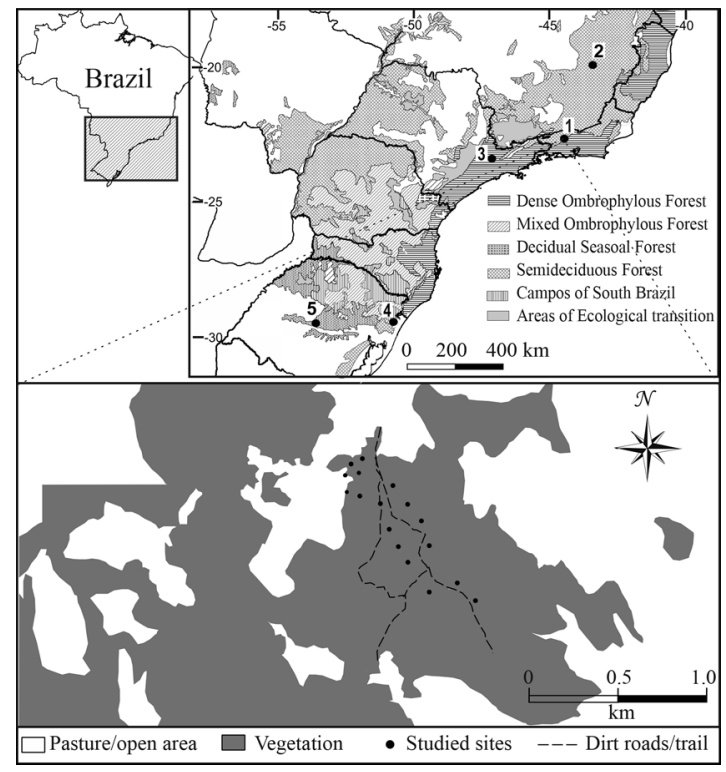

Figure 1 - Instituto Zoobotânico de Morro Azul (1) located in an Atlantic Forest fragment in Rio de Janeiro, Brazil. Studies on ectoparasitic flies carried out in the Atlantic Forest of southern and southeastern Brazil: Parque Estadual do Rio Doce (2); Parque Estadual da Cantareira (3); Fundação Estadual de Pesquisa Agropecuária (4) and Morro do Elefante (5). The types of vegetation are classified following SOSMA and INPE (2011).

Gardner (2008), and descriptions from Reis et al. (2007). Each specimen was placed separately in a numbered cloth bag. After observing the fur, wings and uropatagium of each bat, the ectoparasites were manually collected using entomological fine-tipped tweezers; the cloth bags used for bat contention were also checked for the presence of streblids, and they were not reused in the same night. After the examination and removal of ectoparasites, two external measurements of bats were taken, forearm length ( $\mathrm{mm}$ ) and body mass $(\mathrm{g})$, and then bats were released at their place of capture. Those bats that could not be identified in the field were fixed in alcohol $70^{\circ} \mathrm{GL}$ and were, together with their ectoparasites, deposited in Adriano Lúcio Peracchi Collection (ALP), in the Institute of Biology, Universidade Federal Rural do Rio de Janeiro (UFRRJ).

Ectoparasites were individually stored in labelled vials containing alcohol $70^{\circ} \mathrm{GL}$ and were posteriorly identified in the laboratory following Wenzel et al. (1966), Wenzel (1976), Guerrero (1993, 1994a, 1994b, 1995a, 1995b, 1996) and Graciolli and Carvalho (2001), under a stereoscopic microscope.

Bat taxonomy followed Gardner (2008); for ectoparasitic flies we followed Guerrero (1997).

The following parasitological indexes were calculated following Bush et al. (1997): prevalence (number of infested bats/number of examined bats), mean intensity (number of ectoparasites/number of infested bats) and mean abundance (number of ectoparasites/number of ex- 
amined bats). We assessed the confidence interval for the prevalence and mean abundance values at $95 \%$. Analyses were carried out for all bat species in the program Quantitative Parasitology 3.0 (Rózsa et al., 2000).

To calculate streblid richness, Margalef's index was used, with the formula $\alpha=(\mathrm{S}-1) / \ln N$, where $S$ is the number of species sampled, $N$ is the total number of individuals found in the sample, and $\ln N$ is the Neperian logarithm of $N$ (Melo, 2008). For this analysis we used the statistical package PAST 1.92 (Hammer et al., 2006) with Bootstrap of $95 \%$ IC.

The expected richness of streblids was estimated with Chao 1 index (Chao, 1984), with the formula: $S C h a o=S_{o b s}+\left(\mathrm{a}^{2} / 2 \mathrm{~b}\right)$, where $S_{o b s}$ is the number of species observed, $a$ is the number of species observed only once and $b$ is the number of species observed twice. We used the statistical package SPADE for those calculations (Chao and Shen, 2009).

Richness index and richness estimate (Chao 1) were also calculated for four published studies on assemblages of ectoparasitic flies of the family Streblidae carried out in the Atlantic Forest, in different parts of Brazil, at the sites: Morro do Elefante (ME), state of Rio Grande do Sul (Camilotti et al., 2010); Fundação Estadual de Pesquisa Agropecuária (FEPAGRO), Unidade de Maquiné, state of Rio Grande do Sul (Rui and Graciolli, 2005); Parque Estadual da Cantareira (PEC), state of São Paulo (Bertola et al., 2005); Parque Estadual do Rio Doce (PERD), state of Minas Gerais (Azevedo and Linardi, 2002). The choice of these published studies was due to their approach using quantitative data on richness and abundance of streblids of phyllostomid bats in the Atlantic Forest. We considered only records with identification to species.

\section{Results}

We captured 301 bats of seven species, belonging to five phyllostomid genera. The most frequent species were Carollia perspicillata (Linnaeus, 1758) $(65 \%$ of all bats captured) and Anoura caudifer (E. Geoffroy, 1818) $(15 \%)$ (Table 1). Out of the individuals captured in IZMA, only 69 were parasitised, totalling nine species of bat flies, belonging to six Streblidae genera; the most captured species were Trichobius joblingi Wenzel, 1966 (57\% of all individuals sampled) and Trichobius tiptoni (Wenzel, 1976) (13\%) (Table 1).

Some streblid species were found parasitising more than one bat species (Table 1). Trichobius joblingi was found associated with $A$. caudifer, $C$. perspicillata and Glossophaga soricina (Pallas, 1766). Megistopoda aranea (Coquillett, 1899) was associated with Artibeus fimbriatus Gray, 1838 and Artibeus lituratus (Olfers, 1818). Paraeuctenodes longipes Pessôa and Guimarães, 1936 was associated with Anoura geoffroyi Gray, 1838 and $C$. perspicillata. We found up to three different streblid species parasitising a single host, as observed in C. perspicillata and A. lituratus.
The total prevalence was approximately $23 \%$, and the prevalence of each species varied from 1.01 to $33.34 \%$ (13.32 \pm 8.99$)$. Paraeuctenodes longipes, associated with $A$. geoffroyi, was the most prevalent species, and $P$. longipes, associated with $C$. perspicillata, was the least prevalent. The total mean intensity of infestation was 1.83 and values for each species varied from 1.00 to $5.00(1.94 \pm 1.44)$. The highest mean intensity of infestation was observed in P. longipes associated with $A$. geoffroyi, and Paratrichobius longicrus (Miranda Ribeiro, 1907) associated with A. lituratus, both with five ectoparasites per bat on average. The lowest values were observed in T. joblingi parasitising A. caudifer, Aspidoptera phyllostomatis (Perty, 1833) and $M$. aranea parasitising A. lituratus, Strebla guajiro (García and Casal, 1965) and $P$. longipes parasitising $C$. perspicillata, $T$. joblingi parasitising G. soricina and Megistopoda proxima (Séguy, 1926) parasitising Sturnira lilium (E. Geoffroy, 1810), all with one ectoparasite per host on average. Trichobius joblingi exhibited the highest mean abundance of infestation; it was over 3.00 on its host species; the least abundant species was $P$. longipes parasitising $C$. perspicillata (Table 1).

Margalef's index $(\alpha)$ was 1.447 , which was only lower than in the Parque Estadual da Cantareira (PEC) (Table 2). The location that exhibited the lowest value was Morro do Elefante (ME), in the state of Rio Grande do Sul (0.5422). The total number of streblid species estimated for IZMA with Chao 1 index was equivalent to the number of species observed (Nobs $=9$ ). Similar results were obtained in other localities of the Atlantic Forest, in southern and southeastern Brazil (Table 2).

\section{Discussion}

The richness of phyllostomid bats found in the present study is similar to the richness found in other studies carried out in Atlantic Forest fragments in the state of Rio de Janeiro (Baptista and Mello, 2001; Esbérard, 2003), in which $C$. perspicillata exhibits high capture frequency (Dias and Peracchi, 2008; Luz et al., 2011), and most species recorded exhibit broad geographical distribution in Brazil (Reis et al., 2007).

The species richness of streblids obtained in the present study (nine species from five genera) is similar to values observed in studies carried out in other Brazilian physiognomies with different sampling efforts. In remnants of seasonal semi-deciduous submontane forest with cerrado influence, in the state of Paraná (Anderson and Ortêncio-Filho, 2006), six species from five genera were recorded with a similar sampling effort. In woodland and mangrove areas in the state of Maranhão, Santos et al. (2009) obtained a richness of 15 species from eight genera, with $36 \mathrm{~h}$ of sampling effort. Sampling effort is one of the criteria used to compare richness between localities, but in these studies on ectoparasitic flies it is remarkable that those differences depend more on other characteristics inherent to each physiognomy and on the host-species than on sampling effort. All species found in 
França, DS. et al.

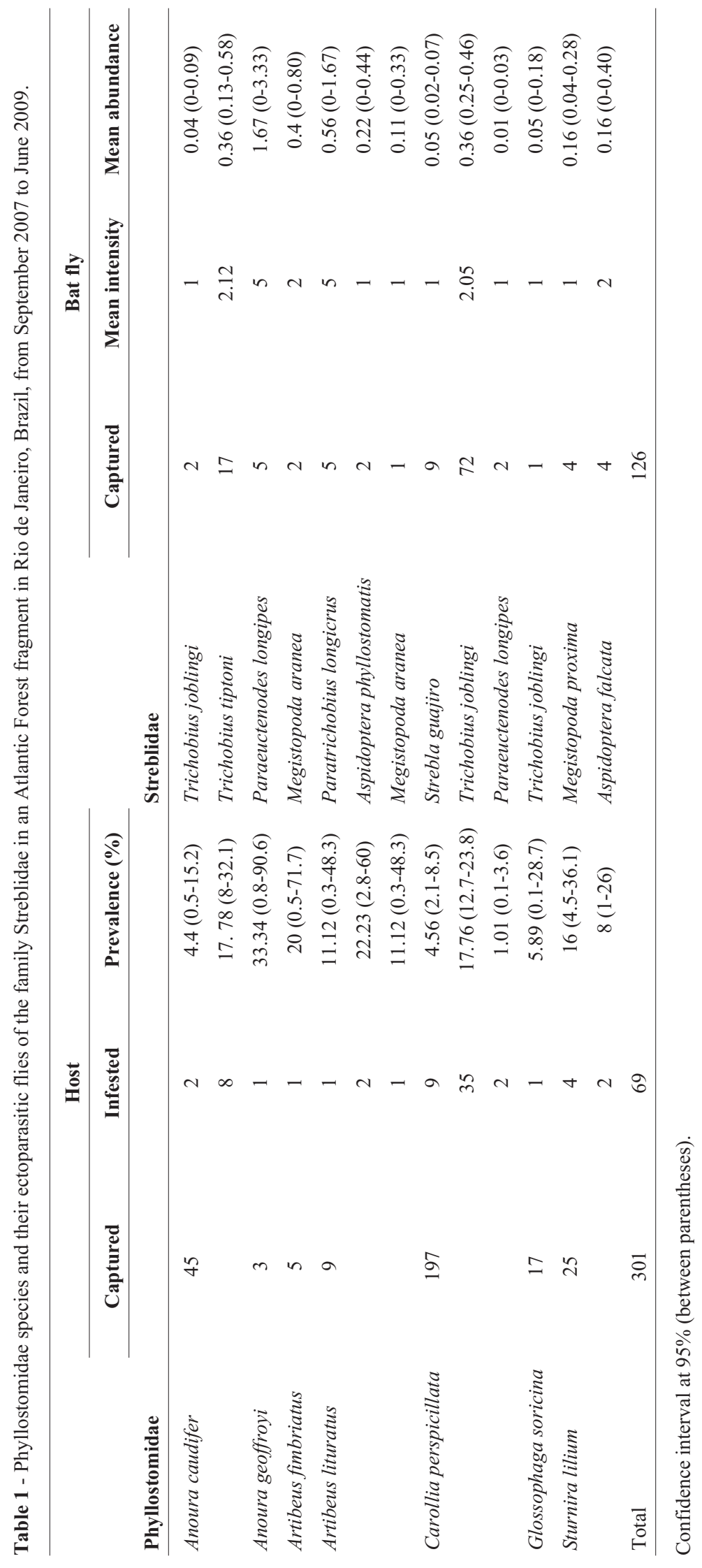


Table 2 - Margalef's index $(\alpha)$ and estimated richness (Chao 1) in studies on ectoparasitic flies carried out in the Atlantic Forest of southern and southeastern Brazil. UF = Unit of Federation; Nobs: number of species observed; N: number of individuals; CI: confidence interval; HS: number of host species; SE: calculated sampling effort (Straube and Bianconi 2002). $a$ : data not available in the literature; $b$ : the software used did not calculate the value of Chao (1) to this location.

\begin{tabular}{lcccccccc}
\hline $\begin{array}{l}\text { Locality / } \\
\text { physiognomy* }\end{array}$ & UF & $\alpha$ & $\mathbf{N}_{\text {obs }}$ & N & Chao (1) & $\mathbf{9 5 \%}$ CI & HS & SE \\
\hline IZMA/SDF & RJ & 1.447 & 9 & 126 & $9.0 \pm 0.0$ & $(9.0-9.0)$ & 7 & $441,600 \mathrm{~m}^{2} \mathrm{~h}$ \\
PERD/SF & $\mathrm{MG}$ & 1.033 & 8 & 48 & $9.0 \pm 1.9$ & $(8.1-19.1)$ & 8 & $a$ \\
PEC/DOF & $\mathrm{SP}$ & 2.158 & 16 & 413 & $16.5 \pm 1.3$ & $(16.0-24.4)$ & 22 & $27,216 \mathrm{~m}^{2} \mathrm{~h}$ \\
FEPAGRO/C-DOF & $\mathrm{RS}$ & 1.048 & 7 & 118 & $7.0 \pm 0.0$ & $(7.0-7.0)$ & 4 & $75,600 \mathrm{~m}^{2} \mathrm{~h}$ \\
ME/DF & $\mathrm{RS}$ & 0.5422 & 4 & 40 & $b$ & $b$ & 9 & $15,120 \mathrm{~m}^{2} \mathrm{~h}$ \\
\hline
\end{tabular}

*IZMA/SDF = Instituto Zoobotânico de Morro Azul/ Semideciduous Forest (Atlantic Forest) (presente study). $\mathrm{PERD} / \mathrm{SF}=$ Parque Estadual do Rio Doce/ Semideciduous Forest (Azevedo and Linardi, 2002).

$\mathrm{PEC} / \mathrm{DOF}=$ Parque Estadual da Cantareira /Dense Ombrophylous Forest (Atlantic Forest) (Bertola et al., 2005).

FEPAGRO/C-DOF = Fundação Estadual de Pesquisa Agropecuária/ Campos of south Brazil (Atlantic Forest) (Rui and Graciolli, 2005).

$\mathrm{ME} / \mathrm{DF}=$ Morro do Elefante /Deciduous Forest (Camilotti et al., 2010).

IZMA were already recorded for Brazil in different regions such as the Mid-Western (Graciolli and Aguiar, 2002; Graciolli et al., 2006a), southern (Rui and Graciolli, 2005; Graciolli and Bianconi, 2007; Silva and Ortêncio-Filho, 2011) and northeast of the country (Santos et al., 2009; Dias et al., 2009). Among the nine streblid species recorded in the present study, just $P$. longipes was not even recorded in the Atlantic Forest of southeastern Brazil (Azevedo and Linardi, 2002; Bertola et al., 2005; Graciolli et al., 2006b).

The most frequently collected Streblidae species, $T$. joblingi, is very abundant in southeastern Brazil (Komeno and Linhares, 1999; Azevedo and Linardi, 2002), whereas in southern Brazil, many inventories (Graciolli and Rui, 2001; Rui and Graciolli, 2005; Camilotti, 2010) point to this streblid species as less abundant in the region. The association of $T$. jobling $i$ with more than one host species was also recorded in several studies (Graciolli and Bernard, 2002; Bertola et al., 2005; Dias et al., 2009; Santos et al., 2009). Although this fly species is a primary ectoparasite of $C$. perspicillata, $T$. joblingi can be found on many other bat species (Guerrero, 1995a). However, these records may have their occurrences considered accidental. The non-primary host-parasite relationship may result from human influence or error (inadequate collection methods or the proximity of shelters used by different species of bats) (Graciolli and Carvalho, 2001; Dick, 2007).

Carollia perspicillata has a broad geographical distribution from Mexico to Paraguay (Gardner, 2008); it has been recorded in 26 states, in all regions of Brazil (Peracchi et al., 2010). However, C. perspicillata has lower capture frequency in southern Brazil (Reis et al., 2007); as the distribution of T. joblingi follows the distribution of its host, this is probably why the abundance of this fly is low in southern Brazil (Prevedello et al., 2005).
The association between $M$. aranea and A. fimbriatus and $A$. lituratus had been already recorded for southeastern Brazil (Bertola et al., 2005). Although this species is considered as a primary parasite of $A$. planirostris and $A$. fimbriatus in South America and is found with higher frequency on Artibeus species; M. aranea could be found on other phyllostomid bats, and its presence, in this case, could be a contamination or a transition to the definitive host (Autinoet al.,1992; Komeno and Linhares, 1999). Paraeuctenodes longipes, which exhibits as its primary host $A$. caudifer, was recorded parasitising $A$. geoffroyi and $C$. perspicillata for the first time in southeastern Brazil. This streblid species can be found on other hosts (Graciolli and Carvalho, 2001), but the associations found may result from co-habitation between host species (Trajano and Gnaspini-Netto, 1991) or from the low frequency of capture of $A$. caudifer in IZMA. Aspidoptera phyllostomatis has already been recorded for southeastern Brazil, though associated with S. lilium in an occurrence classified as accidental (Graciolli et al., 2006b), since this streblid is usually found on Artibeus species. However, there are records of A. phyllostomatis on species of the genus Sturnira in Argentina (Autino et al., 2009).

Concerning host-parasite relationships, the total prevalence of bat ectoparasites was higher than the values of $20 \%$ observed in the state of Rio Grande de Sul (Rui and Graciolli, 2005) and 19\% in Paraná (Anderson and Ortêncio-Filho, 2006), and lower than the values of 32\% recorded by Santos et al. (2009) and of 36\% recorded by Bertola et al. (2005). Paraeuctenodes longipes exhibited the highest prevalence on $A$. geoffroyi and the lowest prevalence on $C$. perspicillata (Table 1), due to the proportion of bats collected in relation to the bats infested by this streblid species (Graciolli and Carvalho, 2001). The total mean intensity in IZMA was lower than the one observed by Santos et al. (2009), on average four streblids 
per infested bat. The highest mean intensities were observed for $P$. longipes parasitising A. geoffroyi, which had not been recorded before in taxonomic inventories or in infestation analyses (Azevedo and Linardi, 2002; Komeno and Linhares, 1999; Bertola et al., 2005; Rui and Graciolli, 2005; Graciolli et al., 2006b; Graciolli and Aguiar, 2002; Dias et al., 2009; Silva and Ortêncio-Filho, 2011). The mean abundance calculated in the present study was higher than the values observed by Komeno and Linhares (1999) in the state of Minas Gerais (1.4) and by Bertola et al. (2005) in the state of São Paulo (1.24). This result suggests higher infestation by ectoparasitic flies in bat populations of Rio de Janeiro compared with other states in southeastern Brazil. The differences in the host-parasite relationships in IZMA compared with other localities can result from environmental characteristics, such as climatic conditions, physiognomy and altitude (Krasnov et al., 2005; Vinarski et al., 2007), which influence species richness and the type of roost used (Rui and Graciolli, 2005), ultimately affecting the composition of the bat fly assemblage in the region.

Margalef's index exhibited values below 2 in the studies carried out by Azevedo and Linardi (2002), Rui and Graciolli (2005) and Camilotti et al. (2010), as well as in the present study (Table 2). This could be explained by the predominance of some streblid species in detriment of other less frequent ones. Those low values are common in poorly preserved localities where human activity is high; that is not the case of the localities analysed, most of which were well preserved. However, species richness in IZMA was higher than in FEPAGRO (Rui and Graciolli, 2005), an area also covered by dense rainforest, with second-growth forest in different stages of succession. FEPAGRO is inserted in Maquiné Valley, state of Rio Grande do Sul, which has flat and fertile areas for agriculture. Human activity can justify the low species richness of streblids.

In Morro do Elefante the low richness found is justified by the very low annual average temperature (minimum of $9.3^{\circ} \mathrm{C}$ ) and by the type of vegetation, in which bat richness is usually lower than in the Atlantic Forest of southern Brazil (Weber, 2009). Through the richness estimator Chao 1 calculated for the streblid assemblages in the Atlantic Forest (Table 2), it was possible to observe that in some localities the expected richness is similar to the observed richness, despite differences in sampling effort among inventories. For a deeper analysis it is important to consider also the number of sites sampled in each locality, as higher sampling effort leads to higher capture efficiency and consequently enables a better sampling of the richness of the region (Esberard, 2006).

The present study described the richness and abundance of bat flies in an Atlantic Forest fragment, aiming to contribute in the advancement of knowledge on the distribution of ectoparasitic fly species and their associations with bats in the Atlantic Forest of southeastern Brazil and, in particular, of the state of Rio de Janeiro, where there is a huge need for studies. Additional studies in other localities are needed to properly document the assemblages of dipteran ectoparasites of bats and to provide a better understanding of the structure of those parasitic communities and of the relationships between ectoparasites and their hosts.

\section{Acknowledgments}

We thank the Instituto Zoobotânico de Morro Azul, in particular its director Hélio Freitas Santos, for the support granted to perform this research and Francisco Racca Filho for helping in species identification. Funding: Conselho Nacional de Desenvolvimento Científico e Tecnológico (CNPq), the Fundação Carlos Chagas Filho de Amparo à Pesquisa do Estado do Rio de Janeiro (FAPERJ) and the Coordenação de Aperfeiçoamento de Pessoal de Nível Superior (CAPES). Sampling permit granted by the Instituto Chico Mendes de Conservação da Biodiversidade (ICMBIO/SISBIO/15809).

\section{References}

ANDERSON, R. and ORTÊNCIO-FILHO, H., 2006. Dípteros ectoparasitas (Diptera, Streblidae) de filostomídeos (Chiroptera, Mammalia) do Parque Municipal no Cinturão Verde de Cianorte, Paraná, Brasil e sua incidência ao longo das estações do ano. Chiroptera Neotropical, vol. 12 , no. 1 , p. 238-243.

AUTINO, AG., BARQUEZ, RM. and CLAPS, GL., 1992. Nuevas citas de dipteros ectoparasitos (Streblidae) para murciélagos de la Argentina. Revista de la Sociedad Entomológica Argentina, vol. 50, no. 1-4, p. 248-260.

AUTINO, AG., CLAPS, GL., SÁNCHEZ, MS. and BARQUEZ, RM., 2009. New records of bat ectoparasites (Diptera, Hemiptera and Siphonaptera) from northern Argentina. Neotropical Entomology, vol. 38, no. 2, p. 165-177.

AZEVEDO, AA. and LINARDI, PM., 2002. Streblidae (Diptera) of phyllostomid bats from Minas Gerais, Brazil. Memórias do Instituto Oswaldo Cruz, vol. 97, no. 3, p. 421-422.

BAPTISTA, M. and MELLO, MAR., 2001. Preliminary inventory of the bat species of the Poço das Antas Reserve, RJ. Chiroptera Neotropical, vol. 7, no. 1-2, p. 133-135.

BERTOLA, PB., AIRES, CC., FAVORITO, SE., GRACIOLLI, G., AMAKU, M. and PINTO-DA-ROCHA, R., 2005. Bat flies (Diptera: Streblidae, Nycteribiidae) parasitic on bats (Mammalia: Chiroptera) at Parque Estadual da Cantareira, São Paulo, Brazil: parasitism rates and host-parasite associations. Memórias do Instituto Oswaldo Cruz, vol. 100 , no. 1 , p. 25-32.

BUSH, AO., LAFFERTY, KD., LOTZ, JM. and SHOSTAK, AW., 1997. Parasitology meets ecology on its own terms. Margolis et al. Revisited. Journal of Parasitology, vol. 83, no. 4 , p. 575-583.

CAMILOTTI, VL., GRACIOLLI, G., WEBER, MM., ARRUDA, JLS. and CÁCERES, NC., 2010. Bat flies from the deciduous Atlantic Forest in southern Brazil: Host-parasite relationships and parasitism rates. Acta Parasitologica, vol. 55, no. 2, p. 194-200.

CHAO, A., 1984. Nonparametric estimation of the number of classes in a population. Scandinavian Journal of Statistics, vol. 11, no. 4, p. 265-270.

CHAO, A. and SHEN, T., 2009. Spade: Species Prediction and Diversity Estimation. Available from: http://chao.stat.nthu.edu.tw/. Access in: 06 apr. 2011. 
DIAS, D. and PERACCHI, AL., 2008. Quirópteros da Reserva Biológica do Tinguá, estado do Rio de Janeiro, sudeste do Brasil (Mammalia, Chiroptera). Revista Brasileira de Zoologia, vol. 25, no. 2, p. 333-369.

DIAS, PAD., SANTOS, CLC., RODRIGUES, FS., ROSA, LC., LOBATO, KS. and REBELO, JMM., 2009. Espécies de moscas ectoparasitas (Diptera, Hippoboscoidea) de morcegos (Mammalia, Chiroptera) no estado do Maranhão. Revista Brasileira de Entomologia, vol. 53, p. 128-133.

DICK, CW., 2007. High host specificity of obligate ectoparasites. Ecological Entomology, vol. 32, p. 446-450.

DICK, CW. and PATTERSON, BD., 2007. Against all odds: explaining host specificity in dispersal-prone ectoparasites. International Journal for Parasitology, vol. 37, p. 871876.

DITTMAR, K., PORTER, ML., MURRAY, S. and WHITING, MF., 2006. Molecular phylogenetic analysis of nycteribiid and streblid bat flies (Diptera: Brachycera, Calyptratae): implications for host associations and phylogeographic origins. Molecular Phylogenetics and Evolution, vol. 38, no. 1, p. 155-170.

EMMONS, LH. and FEER, F., 1997. Neotropical rainforest mammals: a field guide. 2nd ed. Chicago: The University of Chicago Press. 392 p.

ERIKSSON, A., GRACIOLLI, G. and FISCHER, E., 2011. Bat flies on phyllostomid hosts in the Cerrado region: component community, prevalence and intensity of parasitism. Memórias do Instituto Oswaldo Cruz, vol. 106, no. 3, p. 274-278.

ESBÉRARD, CEL., 2003. Diversidade de morcegos em uma área de Mata Atlântica regenerada no sudeste do Brasil (Mammalia: Chiroptera). Revista Brasileira de Zoociências, vol. 5, no. 2, p. 189-204.

ESBÉRARD, CEL. and BERGALLO, HG., 2005. Coletar morcegos por 6 ou 12 horas a cada noite? Revista Brasileira de Zoologia, vol. 22, no. 4, p. 1095-1098.

ESBÉRARD, CEL., 2006. Efeito da coleta de morcegos por noites seguidas no mesmo local. Revista Brasileira de Zoologia, vol. 23, no. 4, p. 1093-1096.

ESBÉRARD, CEL., ASTÚA, D., GEISE, L., COSTA, LM. and PEREIRA, LG., 2012. Do young Carollia perspicillata (Chiroptera: Phyllostomidae) present higher infestation rates of Streblidae (Diptera)? Brazilian Journal of Biology, vol. 72, no. 3, p. 617-621.

FURUSAWA, GP. and CASSINO, PCR., 2006. Ocorrência e distribuição de Calliphoridae (Diptera, Oestroidea) em um fragmento de Mata Atlântica Secundária no Município de Engenheiro Paulo de Frontin, Médio Paraíba, RJ. Revista de Biologia e Ciências da Terra, vol. 6, no. 1, p. $152-164$.

GARDNER, AL., 2008. Mammals of South America: marsupials, xenarthrans, shrews, and bats. Chicago: University of Chicago Press. 669 p.

GRACIOLLI, G. and CARVALHO, CJB., 2001. Moscas ectoparasitas (Diptera, Hippoboscoidea, Nycteribiidae) de morcegos (Mammalia, Chiroptera) do Estado do Paraná, Brasil. I Basilia, taxonomia e chave pictórica para as espécies. Revista Brasileira de Zoologia, vol. 18, no. 1, p. 33-49.

GRACIOLLI, G. and RUI, AM., 2001. Streblidae (Diptera, Hippoboscoidea) em morcegos (Chiroptera, Phyllostomidae) no nordeste do Rio Grande do Sul, Brasil. Iheringia, Série Zoologia, vol. 90, p. 85-92.

GRACIOLLI, G. and AGUIAR, LS., 2002. Ocorrência de moscas ectoparasitas (Diptera, Streblidae e Nycteribiidae) de morcegos (Mammalia, Chiroptera) no Cerrado de Brasí- lia, Distrito Federal, Brasil. Revista Brasileira de Zoologia, vol. 19, p. 177- 181

GRACIOLLI, G. and BERNARD, E., 2002. Novos registros de moscas ectoparasitas (Díptera, Streblidae e Nycteribiidae) em morcegos (Mammalia, Chiroptera) do Amazonas e Pará, Brasil. Revista Brasileira de Zoologia, vol. 19, p. 77-86.

GRACIOLLI, G. and LINARDI, PM., 2002. Some Streblidae and Nycteriibidae (Diptera: Hippoboscoidea) from Maracá Island, Roraima, Brazil. Memórias do Instituto Oswaldo Cruz, vol. 97, no. 1, p. 139-141.

GRACIOLLI, G., CÁCERES, NC. and BORNSCHEIN, MR., 2006a. Novos registros de moscas ectoparasitas (Diptera, Streblidae e Nycteribiidae) de morcegos (Mammalia, Chiroptera) em áreas de transição Cerrado-floresta estacional no Mato Grosso do Sul, Brasil. Biota Neotropica, vol. 6, no. 2. Available from: http://www.biotaneotropica. org.br/v6n2/pt/abstract?short-communication+bn03206022006.

ISSN 1676-0603. Access in: 06 Apr. 2011.

GRACIOLLI, G., PASSOS, FC., PEDRO, WA. and LIM, BK., 2006b. Moscas ectoparasitas (Diptera: Streblidae) de morcegos filostomídeos (Mammalia, Chiroptera) na Estação Ecológica dos Caetetus, São Paulo, Brasil. Revista Brasileira Zoologia, vol. 23, no. 1, p. 298-299.

GRACIOLLI, G. and BIANCONI, GV., 2007. Moscas ectoparasitas (Diptera, Streblidae e Nycteribiidae) em morcegos (Mammalia, Chiroptera) em área de Floresta com Araucária no Estado do Paraná, sul do Brasil. Revista Brasileira de Zoologia, vol. 24, no. 1, p. 246-249.

GRACIOLLI, G. and AZEVEDO, AA., 2011. Ectoparasites of bats (Chiroptera, Furipteridae), with a description of a new species of Synthesiostrebla Townsend (Diptera, Streblidae) from Brazil. Revista Brasileira de Entomologia [online], vol. 55, no. 4, p. 501-504.

GRACIOLLI, G. and DICK, CW., 2012. Description of a second species of Joblingia Dybas \& Wenzel, 1947 (Diptera: Streblidae). Systematic Parasitology, vol. 81, no. 3, p. 187-193.

GUERRERO, R., 1993. Catalogo de los Streblidae (Diptera: Pupipara) parasitos de murciélagos (Mammalia: Chiroptera) del Nuevo Mundo. I. Clave para los gêneros y Nycterophilinae. Acta Biologica Venezuelica, vol. 14, p. 61-75.

GUERRERO, R., 1994a. Catalogo de los Streblidae (Diptera: Pupipara) parasitos de murciélagos (Mammalia: Chiroptera) del Nuevo Mundo. II. Los grupos: pallidus, caecus, major, uniformis y longipes del género Trichobius Gervais, 1844. Acta Biologica Venezuelica, vol. 15, no. 1, p. 1-18.

GUERRERO, R., 1994b. Catalogo de los Streblidae (Diptera: Pupipara) parasitos de murciélagos (Mammalia: Chiroptera) del Nuevo Mundo. IV. Trichobiinae com alas desarrolladas. Boletín Entomologica Venezolana, Nueva Serie, vol. 9, no. 2, p. 161-192.

GUERRERO, R., 1995a. Catalogo de los Streblidae (Diptera: Pupipara) parasitos de murciélagos (Mammalia: Chiroptera) del Nuevo Mundo. III. Los gupos: dugesii, dunni y phyllostomae del género Trichobius Gervais, 1844. Acta Biological Venezuelica, vol. 15, no. 3-4, p. 1-27.

GUERRERO, R., 1995b. Catalogo de los Streblidae (Diptera: Pupipara) parasitos de murciélagos (Mammalia: Chiroptera) del Nuevo Mundo. V. Trichobiinae con alas reducidas o ausentes y miscelaneos. Boletín Entomologica Venezolana, vol. 10, no. 2, p. 135-160. 
GUERRERO, R., 1996. Catalogo de los Streblidae (Diptera: Pupipara) parasitos de murciélagos (Mammalia: Chiroptera) del Nuevo Mundo. VI. Streblinae. Acta Biologica Venezolana, vol. 16, no. 2, p. 1-25.

GUERRERO, R., 1997. Catalogo de los Streblidae (Diptera: Pupipara) parasitos de murcielagos (Mammalia: Chiroptera) del nuevo mundo. VII. Lista de especies, hospedadores y paises. Acta Biologica Venezolana, vol. 17, no. 1, p. 9-24

HAMMER, O., HARPER, DAT. and RYAN, PD., 2006. Paleontological Statistics - PAST ver. 1.92. Available from: folk.uio.no/ohammer/past. Accessed in: 06 Apr. 2011.

KOMENO, CA. and LINHARES, AX., 1999. Bat flies parasitic on some phyllostomid bats in Southeastern Brazil: parasitism rates and host-parasite relationships. Memórias do Instituto Oswaldo Cruz, vol. 94, no. 2, p. 151-156.

KRASNOV, BR., SHENBROT, GI., MOUILLOT, D., KHOKHLOVA, IS. and POULIN, R., 2005. Spatial variation in species diversity and composition of flea assemblages in small mammalian host; geographic distance or faunal similarity? Journal of Biogeography, vol. 32, no. 4, p. 633-644.

LUZ, JL., COSTA, LM., LOURENÇO, EC. and ESBÉRARD, CEL., 2001. Bats (Mammalia, Chiroptera) from Reserva Rio das Pedras, Rio de Janeiro, Southeastern Brazil. Biota Neotropica, vol. 11, no. 1, p. 1-7.

MARSHALL, AG., 1981. The Ecology of Ectoparasitc Insects. London: Academic Press. 459 p.

MARSHALL, AG., 1982. Ecology of insects ectoparasitic on bats. In KUNZ, TH. (Ed.). Ecology of bats. New York: Plenum Publishing. p. 369-401.

MELO, AS., 2008. O que ganhamos 'confundindo' riqueza de espécies e equabilidade em um índice de diversidade? Biota Neotropica, vol. 8, no. 3, p. 21-27.

PATTERSON, BD., DICK, CW. and DITTMAR, K., 2007. Roosting habits of bats affect their parasitism by bat flies (Diptera: Streblidae). Journal of Tropical Ecology, vol. 23, p. 177-189.

PERACCHI, AL., GALLO, PH., DIAS, D., LIMA, IP. and REIS, NR., 2010. Ordem Chiroptera. In REIS, NR., PERACCHI, AL., ROSSANEIS, BK. and FREGONEZI, MN. (Eds.). Mamíferos do Brasil - Guia de Identificação. Londrina: Technical Books. p. 293-261.

PREVEDELLO, JA., GRACIOLLI, G. and CARVALHO, CJB., 2005. A Fauna de dípteros (Streblidae e Nycteribiidae) ectoparasitos de morcegos (Chiroptera) do Estado do Paraná, Brasil: Composição, distribuição e áreas prioritárias para novos estudos. Biociências, vol. 13, no. 2, p. 193-209.
REIS, NR., PERACCHI, AL., PEDRO, WA. and LIMA, IP., 2007. Morcegos do Brasil. Londrina: NR. Reis. 253 p.

RÓZSA, L., REICZIGEL, J. and MAJOROS, G., 2000. Quantifying parasites in samples of hosts. Journal of Parasitology, vol. 86, no. 2, p. 228-232.

RUI, AM. and GRACIOLLI, G., 2005. Moscas ectoparasitas (Diptera, Streblidae) de morcegos (Chiroptera, Phyllostomidae) no sul do Brasil: associações hospedeirosparasitos e taxas de infestação. Revista Brasileira de Zoologia, vol. 22, p. 438-445.

SANTOS, CLC., DIAS, PAD., RODRIGUES, FS., LOBATO, KS., ROSA, LC., OLIVEIRA, TG. and REBELO, JMM., 2009. Moscas ectoparasitas (Diptera: Streblidae) de morcegos (Mammalia: Chiroptera) do Municipio de São Luiz, MA: Taxas de Infestação e associações parasito-hospedeiro. Neotropical Entomology, vol. 38, no. 5, p. 595-601.

SILVA, JRR. and ORTÊNCIO-FILHO, H., 2011. Dípteros ectoparasitas (Insecta, Diptera) em morcegos (Chiroptera, Mammalia) na Reserva Biológica das Perobas Paraná, Brasil. Iheringia, Série Zoologia, vol. 101, no. 3, p. 220224.

SOSMA, and INPE. 2011. Atlas dos Remanescentes Florestais da Mata Atlântica - periodo 2008-2010. Available from: http://mapas.sosma.org.br/site_media/download/atlas_2008-10_relatorio\%20final_versao2 julho2011.pdf. Access in: $0 \overline{1}$ nov. 2012.

STRAUBE, FC. and BIANCONI, GV., 2002. Sobre a grandeza e a unidade utilizada para estimar esforço de captura com utilização de redes-de-neblina. Chiroptera Neotropical, vol. 8, no. 1-2, p. 150-152.

TRAJANO, E. and GNASPINI-NETTO, P., 1991. Composição da fauna cavernícola brasileira, com uma análise da distribuição dos táxons. Revista Brasileira de Zoologia, vol. 7, no. 3, p. 383-407.

VINARSKI, MV., KORALLO, NP., KRASNOV, BR., SHENBROT, GI. and POULIN, R., 2007. Decay of similarity of gamasid mite assemblages parasitic on Paleartic smalls mammals: geographic distance, host-species composition or environment. Journal of Biogeography, vol. 34, no. 10, p. 1691-1700.

WEBER, MM., 2009. Biogeografia de morcegos (Chiroptera) em área de transição floresta-campo no sudeste da América do Sul. 75 p. Santa Maria: Universidade Federal de Santa Maria. Dissertação de Mestrado.

WENZEL, RL., 1976. The streblid bat flies of Venezuela (Diptera: Streblidae). Brighan Young University Science Bulletin, Biological Series, vol. 20, no. 4, p. 1-177.

WENZEL, RL., TIPTON, VJ. and KIEWLICZ, A., 1966. The streblid bat flies of Panama (Diptera: Calyptera: Streblidae). In WENZEL, RL. and TIPTON, VJ. (Eds.). Ectoparasites of Panama. Chicago: Field Museum of Natural History, p. 405-675. 